Article

\title{
Evaluation of Pectin Extraction Conditions and Polyphenol Profile from Citrus $x$ lantifolia Waste: Potential Application as Functional Ingredients
}

\author{
Teresa del Rosario Ayora-Talavera ${ }^{1}$, Cristina A. Ramos-Chan ${ }^{1}$, Ana G. Covarrubias-Cárdenas ${ }^{1}$, \\ Angeles Sánchez-Contreras ${ }^{1}$, Ulises García-Cruz ${ }^{2}$ and Neith A. Pacheco L. ${ }^{1, *}$ \\ 1 Centro de Investigación y Asistencia en Tecnología y Diseño del Estado de Jalisco CIATEJ Unidad Sureste. \\ Parque Científico Tecnológico de Yucatán, Km 5.5 Carretera Sierra Papacal-Chuburná puerto, \\ Mérida-CP 97302, México; tayora@ciatej.mx (T.d.R.A.-T.); arapachecol@gmail.com (C.A.R.-C.); \\ covarrubias.ana@hotmail.com (A.G.C.-C.); msanchez@ciatej.mx (A.S.-C.) \\ 2 Centro de Investigación y Estudios Avanzados del Instituto Politécnico Nacional. Unidad Mérida Km. 6 \\ Antigua carretera a Progreso Apdo. Postal 73, Cordemex, Mérida Yuc. 97310, México; \\ norbertoulisesg@gmail.com \\ * Correspondence: npacheco@ciatej.mx; Tel.: +52-33-3345-5200 (ext. 4024)
}

Academic Editors: Johnselvakumar Lawrence and Karunanithy Chinnadurai Received: 4 January 2017; Accepted: 10 March 2017; Published: 15 March 2017

\begin{abstract}
The citrus by-products pectin and polyphenols were obtained from Citrus x lantifolia residues. The use of acid type, solute-solvent ratio, temperature, and extraction time on pectin yield recovery was evaluated using a factorial design $3^{4}$; pectin physicochemical characterization, polyphenol profile, and antioxidant activity were also determined. Results indicated a total polyphenol content of $3.92 \pm 0.06 \mathrm{mg}$ Galic Acid Equivalents (GAE)/g of citrus waste flour in dry basis (DB), with antioxidant activity of $74 \%$. The presence of neohesperidin $(0.96 \pm 0.09 \mathrm{mg} / \mathrm{g}$ of citrus flour DB), hesperidin $(0.27 \pm 0.0 \mathrm{mg} / \mathrm{g}$ of citrus flour DB), and ellagic acid $(0.18 \pm 0.03 \mathrm{mg} / \mathrm{g}$ of citrus flour DB) as major polyphenols was observed. All of the factors evaluated in pectin recovery presented significant effects $(p<0.05)$, nevertheless the acid type and solute-solvent ratio showed the greatest effect. The highest yield of pectin recovery $(36 \%)$ was obtained at $90{ }^{\circ} \mathrm{C}$ for $90 \mathrm{~min}$, at a ratio of 1:80 $(w / v)$ using citric acid. The evaluation of pectin used as a food ingredient in cookies elaboration, resulted in a reduction of $10 \%$ of fat material without significant texture differences $(p<0.05)$. The pectin extraction conditions and characterization from these residues allowed us to determine the future applications of these materials for use in several commercial applications.
\end{abstract}

Keywords: citrus polyphenols; citrus pectin; Citrus $x$ lantifolia; pectin extraction conditions

\section{Introduction}

The citrus industry in Mexico represents an important economic and social activity. Worldwide, Mexico occupies the fifth place in citrus production; particularly, lemons represent the second most commonly produced citrus fruit in this country, where Citrus $x$ lantifolia represents $50 \%$ of the citrus crop cultivated in Mexico [1]. Most of the citrus production is intended for fresh consumption; the rest is industrially transformed for the elaboration of juices, pulps, and fruit concentrates. Nevertheless, around $45 \%$ of the fruit is wasted; thus as production increases, the generation of solid and liquid waste also increases, which represents significant amounts of by-products not fully industrially exploited [2]. Nowadays, in order to reduce the environmental impact caused by waste materials from food industry, alternatives to obtain added value products that could be exploited in different areas are necessary; as an example, the extraction of biological molecules from citrus residues is an important part of an integrated system that could finish in bioethanol production with the residues free from compounds as 
polyphenol and pectins, that can be used to favor fermentation process. Specifically, lemon peels are rich in polyphenolic compounds such as phenolic acids and flavonoids, which have been reported to be responsible for a variety of important biological effects [3]. Some of the biological properties reported by polyphenolic compounds are the reduction of cholesterol and blood sugar levels, anti-cancer effects, blood pressure lowering, anti-inflammatory properties, antimicrobial effects, antioxidant capacity, neuroprotection and cardioprotection, all of which are also of great interest for many industrial sectors [3-5]. Pectin, an acidic hydrocolloid widely used as a food ingredient for its gelling properties, is also an important biomolecule of high industrial interest found in citrus waste; it is considered to be a metabolite of biotechnological interest due to its stabilizing properties. Additionally, due to its high water content and easily adjustable physical properties [6], research regarding its potential uses in medical applications has emerged, for instance, nasal and oral drug delivery $[7,8]$, cancer-target drug and gene delivery $[9,10]$, and tissue engineering and wound healing [10]. Most of the commercial pectin is extracted from apple and citrus peels by the use of chloride acid, nevertheless, the trend of consumers looking to find products obtained in a more environmentally friendly way, searching for the lowest chemical residues generation as well as integrated citric waste utilization, led to the study of new extraction methods in order to maintain or improve upon recovery yields [2]. Furthermore, the prolonged commercial success of pectin has shown the importance of using fruit by-products as raw materials to utilize for production [11]. On the other hand, the use of pectin as an ingredient in bakery products has been suggested as an effective fat replacer [12]; pectin from Yuja (Citrus junos) pomace has been evaluated as an effective fat replacement (up to 10\%) in cakes without volume losses. For that reason, the main objectives of this work were: (i) to determine the polyphenol profile from Citrus $x$ lantifolia flour residues, (ii) to evaluate the principal factors affecting pectin extraction (solvent type, time, temperature, and solute/solvent radio), (iii) to analyze the physicochemical characteristics of the pectin extracted and compare it to a commercial one, and (iv) to evaluate the pectin obtained as a functional ingredient in a bakery product.

\section{Materials and Methods}

\subsection{Biological Materials and Reagents}

The raw material (Persian lime Citrus $x$ latifolia peel, bagasse, and seed) was collected at the Akil Juicer from Union de Ejidos Citricultores, Akil, Yucatan. After juice and essential oils were obtained by mechanical methods (scraping), samples were transported to the research center (CIATEJ) and stored at $-4{ }^{\circ} \mathrm{C}$ until further analysis. Folin-Ciocalteu's phenol, 2,2-diphenyl-1-picrylhydrazyl (DPPH), analytical standards of gallic acid, caffeic acid, ellagic acid, naringin, hesperidin, neohesperidin, morin, quercetin, genistein, kaempferol, methanol and acetonitrile (chromatographic grade), and commercial citrus pectin were purchased in Sigma Aldrich (San Luis, MI, USA). Ultra-pure water was prepared in a Milli-Q water filtration system (Millipore, Bedford, MA, USA).

\subsection{Flour Waste Preparation and Characterization}

Waste products were oven dried at $65^{\circ} \mathrm{C}$ for $48 \mathrm{~h}$ before polyphenol extraction. Moisture content was performed according to NMX-F-428-1982 [13], pH and acidity percentage were determined according to the Association of Official Agricultural Chemists (AOAC) method. Color was measured using a MiniScan Ez colorimeter, and L, a, and b parameters were obtained.

\subsection{Polyphenol Extraction, Total Polyphenol Quantification (TPC), and Antioxidant Activity}

Polyphenol extraction was performed according to the cryogenic methanolic extraction reported in MX/a/2012/014554 patent solicitude and by Sánchez-Contreras et al. [14]. Residual waste after polyphenol extraction was used for pectin recovery. The TPC was determined by Folin-Ciocalteu's phenol method [15], the absorbance was measured in a spectrophotometer (Thermo Scientific, Biomate 3S, Madison, WI, USA) at $760 \mathrm{~nm}$. Estimation of TPC was carried out using gallic 
acid as a standard and the results were expressed in $\mathrm{mg}$ of gallic acid equivalent per gram of citrus waste flour in dry weight (mg GAE/g DW). Antioxidant activity was evaluated using the 2,2-diphenyl-1-picrylhydrazyl (DPPH) scavenging method [16], the absorbance was measured in a spectrophotometer (Thermo Scientific, Biomate 3S, Madison, WI, USA) at $517 \mathrm{~nm}$. The DPPH scavenging activity was evaluated based on the percentage of DPPH radical scavenged according to Equation (1):

$$
S_{D P P H}=S_{b}-\left(S_{c}-S_{s}\right) / S_{b} \times 100
$$

where $S_{D P P H}$ is DPPH radical scavenging activity expressed as a percentage, $S_{b}$ is the A517 $\mathrm{nm}$ of blank treatment, $S c$ is the A517 $\mathrm{nm}$ of sample solution, and $S s$ is the A517 $\mathrm{nm}$ of the background of sample.

\subsection{Polyphenol Identification and Quantification by HPLC}

A mixture of polyphenol standards were considered, containing: gallic acid, ellagic acid, caffeic acid, naringin, hesperidin, neohesperidin, morin, quercetin, genistein, and kaempferol. The retention time of each of the standards was taken as criterion to identify the polyphenol contents in the samples analyzed. To calculate the retention time of each standard, flavonoids were injected individually and the average of 15 individual determinations were taken as retention time value. To quantify the polyphenols identified in the samples, calibration curves of the standards at different concentrations $(1,5,20,50$, and $100 \mathrm{ppm})$ were performed; each concentration was injected in triplicate in order to calculate the time of average retention of each of the flavonoids in the mixture. A Finnigan Surveyor Autosampler Plus Equipment was used, with Finnigan Surveyor PDA Plus Detector, the column used was a Phenomenex, 00F-4435-E0, Gemini $5 \mu, C 18110$ A, $150 \mathrm{~mm} \times 4.60 \mathrm{~mm}, 5$ microns. The injection volume was $25 \mu \mathrm{L}$ and the mobile phases used were A:HPLC water with formic acid $(0.1 \%)$ solvent $\mathrm{B}$ : Acetonitrile with formic acid $(0.1 \%)$, flow rate of $1 \mathrm{~mL} / \mathrm{min}$ and gradient method starting with a minute at $90 \%$ of mobile phase (MP) A, then $40 \mathrm{~min}$ at $74 \%$ of MP A, $30 \mathrm{~min}$ at $35 \%$ of MP A, $5 \mathrm{~min}$ at $100 \%$ of MP B, and lastly, 5 min at $90 \%$ of MP A was performed to equilibrate the system. The determination time was $80 \mathrm{~min}$ at $\lambda=290 \mathrm{~nm}$ and $\lambda=350 \mathrm{~nm}$ detection.

\subsection{Pectin Extraction}

A factorial design $3^{4}$ was used to evaluate the independent variables: acid type (hydrochloric, acetic and citric acid), solute-solvent ratio $(1: 30,1: 50,1: 80)$, temperature $\left(60,75\right.$, and $\left.90^{\circ} \mathrm{C}\right)$, and time extraction (30,60, and $90 \mathrm{~min}$ ) on the pectin yield recovery. Acids were adjusted to $\mathrm{pH} 2.2$. The different acid solutions were placed in flasks of 100 or $250 \mathrm{~mL}$ according to the evaluated solute-solvent ratio, then flasks were heating individually to obtain the temperature proposed in the factorial design, and $2 \mathrm{~g}$ of citrus waste flour free of polyphenols was immersed into the solutions and kept in agitation during the periods of time evaluated. The resulted extracts were cool at ambient temperature and centrifuged at $5300 \mathrm{rpm}$ for $15 \mathrm{~min}$ at $4{ }^{\circ} \mathrm{C}$. The supernatants were further used for pectin recuperation, using ethanol $(96 \% v / v)$ at $1: 2(v / v)$ ratio. The response variable of pectin yield was calculated according to the methods previously used by Baltazar et al. [2] (see Equation (2)), where g of recuperated pectin in DB indicates the weight in grams of the product recuperated after ethanol precipitation and oven drying for $24 \mathrm{~h}$ at $45^{\circ} \mathrm{C}$. The g of initial flour waste in $\mathrm{D}$, represents the weight in grams of the raw material (Citrus $x$ latifolia residues) used in the form of flour.

$$
\text { Pectin YIELD }=\left(\frac{g \text { of recuperated pectin in DB }}{g \text { of initial flour waste in DB }}\right) \times 100
$$

\subsection{Pectin Physicochemical Characterization}

Three different pectin recuperation conditions were evaluated: two stages of acid hydrolysis extraction and alcohol precipitation (A), three stages of acid hydrolysis extraction, alcohol precipitation, and pectin washing $(\mathrm{B})$, two stages of acid hydrolysis extraction with $\mathrm{pH}$ adjustment $(\mathrm{pH}=6.5)$ before alcohol precipitation $(C)$, then the resulting pectins were physicochemically characterized. Free Acidity 
(FA) and Equivalent Weight (EW) were calculated according to [17], FA was expressed as meq of free carboxyl/g and EW was calculated with sample weight $(\mathrm{mg})$ divided by the meq of the $\mathrm{NaOH}$ used for titration. Methoxy Content, Esterification Degree (ED), and Uronic Acid (UA) were calculated according to [18], Methoxy percentage was reported using Equation (3), ED was calculated using Equation (4), and UA was calculated according Equation (5). Identification and pectin conformation were determined according to [19] in order to obtain pectin gels.

$$
\begin{gathered}
\text { Methoxy }(\%)=\frac{\text { meq. of } \mathrm{NaOH} \times \mathrm{MW} \text { of methoxy } \times 100}{\text { sample weight }(\mathrm{mg})} \\
E D(\%)=\frac{\text { meq. of } \mathrm{NaOH}(\text { methoxy content })}{\text { meq. } \mathrm{NaOH}(\text { free acidity })+\text { meq. } \mathrm{NaOH}(\text { methoxy content })} \times 100 \\
U A(\%)=\frac{\text { meq. } \mathrm{NaOH}(\text { free acidity })+\text { meq. } \mathrm{NaOH}(\text { methoxy content })}{\text { sample weight }(\mathrm{mg})} \times 176 \times 100
\end{gathered}
$$

\subsection{Cookie Elaboration, Water Activity $\left(a_{W}\right)$, Water Content $(\%)$, Physical and Textural Determinations}

Cookies were prepared according to [20] with a slight modification, using wheat flour (22\%), sugar $(32 \%)$, vegetal fat $(22 \%)$, egg powder $(10 \%)$, coconut $(7 \%)$, ammonium bicarbonate $(0.5 \%)$, sodium bicarbonate $(0.5 \%)$, raisins $(6 \%)$, and water, then three percentages of the pectin previously obtained were evaluated for fat substitution $(2.5 \%, 7 \%$, and $10 \%)$. Water activity and water content $(\%)$ were measured using an aw equipment Novasina AG (Lachen, Switzerland) and a thermobalance OHAUS MB45-2A0 (Switzerland), respectively. Physical characteristics of the cookies in terms of diameter $(\mathrm{mm})$, thickness $(\mathrm{mm})$, and spread ratio (diameter/thickness) were determined as the average of three measurements, using an electronic digital caliper (Truper) (Jilotepec, Mexico) [21]. Texture analyses were performed as maximal straight (textural hardness) using an EZ-SX Shimadzu Corporation, Japón equipment. Textural hardness was quantified using a three flexion points test. The results were expressed as the average of four measurements [21].

\subsection{Statistical Analysis}

Analysis of Variance (ANOVA) and Tukey comparison test $(p<0.05)$ of the results were determined using the software Statgraphics ${ }^{\circledR}$ Centurion, version XVI (Manugistic, Inc., Rockville, MD, USA). All the results analyzed by comparison test were the average of three independent determinations.

\section{Results}

\subsection{Flour Citrus Waste Characterization}

Previous to polyphenol and pectin extraction the Persian lime Citrus $x$ latifolia waste was oven dried at $65^{\circ} \mathrm{C}$ for $48 \mathrm{~h}$; this procedure was performed in order to reduce water content of the residues to favor material preservation. The results of the physicochemical characterization of the flour obtained after the drying process are shown in Table 1 . The moisture content was around $12 \%$; this value favors preservation of the material during storage, avoiding microbial and enzymatic degradation. The $\mathrm{pH}$ obtained was 3.38 lower than the value obtained in the raw material (data not shown), the total titratable acidity obtained was $7.43 \%$, reported as citric acid meq due to the greatest presence of this acid in lemon [22]. The color determination could provide information about possible sugar caramelization during the drying process, expressed as a brawn color, or degradation of the material with a low luminosity value [22]. As it can be observed in Table 1, color parameter results were related to a yellow color and luminosity was higher than $60 \%$, indicating a well preserved flour. 
Table 1. Physicochemical characterization of the Persian lime Citrus x latifolia flour waste.

\begin{tabular}{|c|c|}
\hline Parameter & Determination \\
\hline Moisture content $\%$ & $12.12 \pm 0.007$ \\
\hline $\mathrm{pH}$ & $3.38 \pm 0.000$ \\
\hline Titratable acidity $\%$ (citric acid meq) & $7.43 \pm 0.288$ \\
\hline Luminosity (L) & $62.63 \pm 0.08$ \\
\hline Parameter a & $6.65 \pm 0.04$ \\
\hline Parameter b & $23.28 \pm 0.070$ \\
\hline
\end{tabular}

\subsection{TPC, Antioxidant Activity and Polyphenol Profile}

As is shown in Table 2, the TPC of citrus waste was $3.92 \pm 0.06 \mathrm{mg}$ of GAE/g of citrus waste flour (DB), and an antioxidant activity of $73.2 \% \pm 4.2 \%$ of $\mathrm{DPPH}^{+}$radical inhibition was observed. The major compound identified was neohesperidin with a concentration of $0.969 \pm 0.099 \mathrm{mg} / \mathrm{g}$ of waste flour in DB, followed by hesperidin, ellagic acid, caffeic acid, morin, and, in lower concentrations, gallic acid, quercetin, kaempferol, and genistein (Table 2).

Table 2. Total polyphenol content, antioxidant activity, polyphenol identification, and concentration determination from citrus waste flour residues.

\begin{tabular}{ccc}
\hline Type of Analysis & Determination & mg/g of Waste Flour in Dry Basis \\
\hline Spectrophotometer & Total Polyphenol content & $3.92 \pm 0.06$ \\
\cline { 2 - 3 } analysis & Antioxidant activity (DPPH + Radical inhibition) & $73.2 \% \pm 4.2 \%$ \\
\hline & Gallic acid content & $0.074 \pm 0.003$ \\
& Caffeic acid content & $0.1560 \pm 0.007$ \\
Ellagic acid content & $0.186 \pm 0.0292$ \\
HPLC * analysis & Naringin content & $0.003 \pm 0.0001$ \\
& Hesperidin content & $0.278 \pm 0.011$ \\
& Neohesperidin & $0.969 \pm 0.099$ \\
& Morin & $0.134 \pm 0.004$ \\
& Quercetin & $0.058 \pm 0.0001$ \\
& Genistein & $0.00045 \pm 0.0001$ \\
\hline
\end{tabular}

* High pressure liquid chromatography; Values are expressed as mean \pm standard deviation.

\subsection{Pectin Extraction}

Based on the factorial experimental design $3^{4}$ the results of the different parameters evaluated on the yield of pectin extraction conditions are shown in Figure 1. Higher pectin yield values were observed at $90^{\circ} \mathrm{C}$ with solute:solvent ratio of 1:80 with the three acids evaluated. Extractions with citric acid resulted in the best pectin yield compared to the others; the maximal pectin yield attained was $36 \%$ using citric acid. The multifactorial analysis of variance (ANOVA) indicated that the interaction of acid type and temperature as well as the four independently evaluated factors presented significant effect $(p<0.05)$ on the pectin extraction yield. According to the Pareto analysis (Figure 2), a major effect was related to acid type being higher with citric acid; solute:solvent ratio also presented a high effect, followed by temperature and time. For all of the factors evaluated, pectin extraction yield increased when the higher levels were evaluated. 


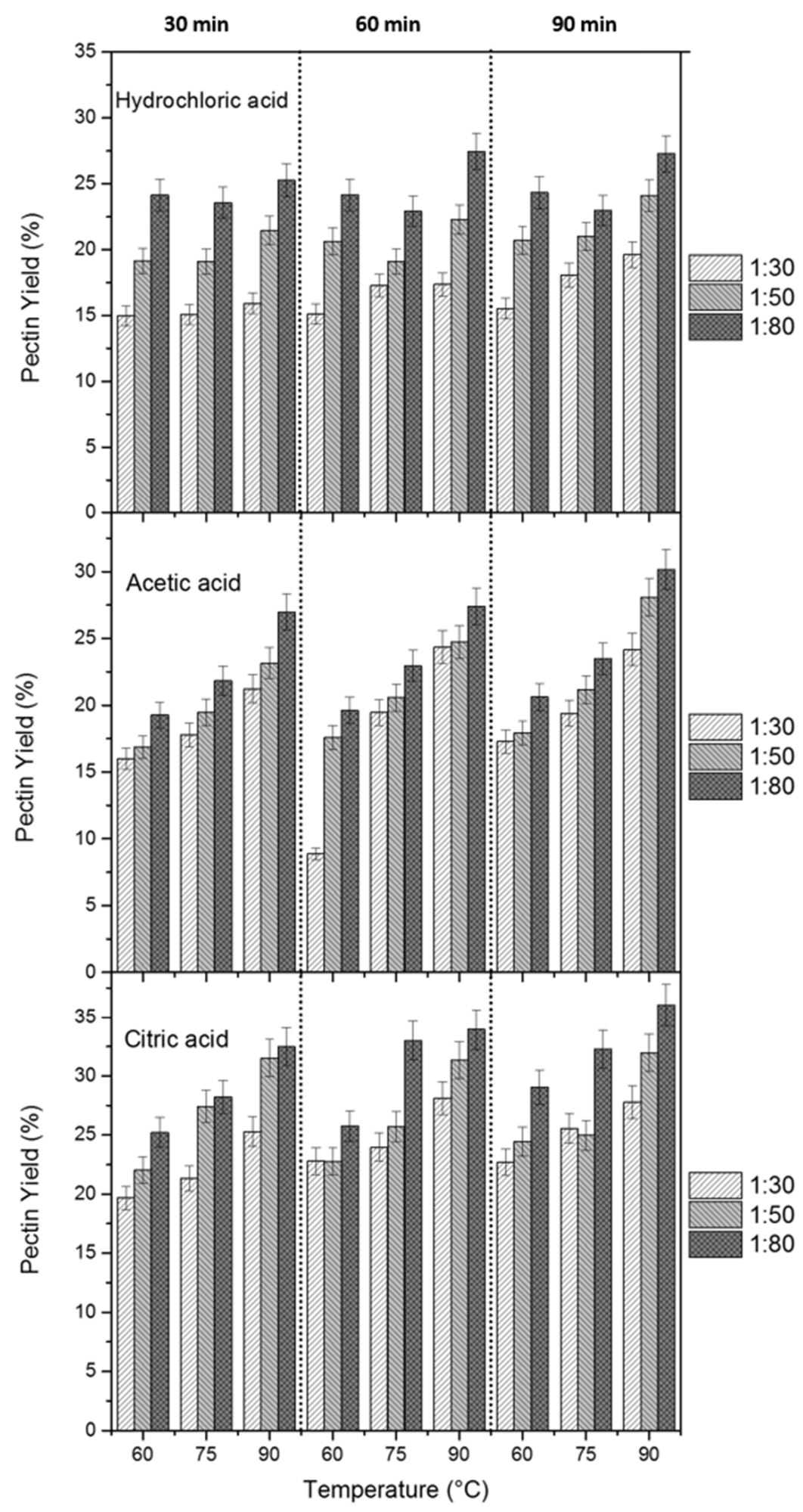

Figure 1. Pectin yield (\%) under different extraction conditions: time (30,60, and $90 \mathrm{~min})$, temperature $\left(60,75\right.$, and $\left.90^{\circ} \mathrm{C}\right)$, solute:solvent ratio (1:30, 1:50, and 1:80), acid type (hydrochloric, acetic, and citric acid). 


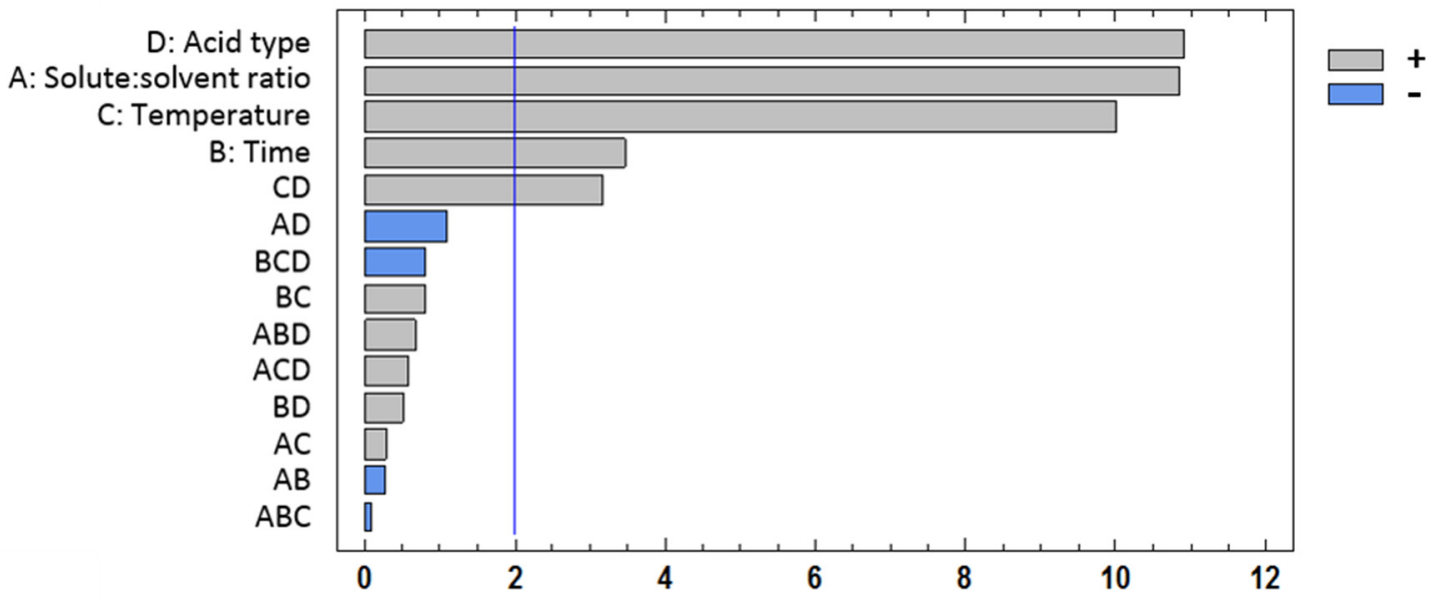

Figure 2. Standardized Pareto analysis of the pectin yield obtained from citrus waste.

\subsection{Physicochemical Pectin Characterization}

The higher pectin yield was obtained with pectin recuperation process $\mathrm{A}$, using the two stage hydrolysis process, and $\mathrm{C}$, with $\mathrm{pH}$ neutralization before alcohol precipitation. Moisture content values obtained with treatments A and B did not show significant differences $(p<0.05)$ between them, but were lower than the values presented in commercial citric pectin and treatment $C$ (Table 3 ). The titratable acidity expressed as meq of free carboxyl/g of sample indicated that the recuperation procedure A exhibited the higher value; this could be due to the residual citric acid presented in the sample. The equivalent weight was lower using the recuperation procedure A and higher with procedure $\mathrm{C}$ when solution was neutralized before precipitation.

Table 3. Physicochemical characterization of pectins obtained from flour citric waste.

\begin{tabular}{|c|c|c|c|c|}
\hline \multirow[t]{2}{*}{ Physicochemical Characteristic } & \multicolumn{3}{|c|}{ Pectin According to Recuperation Process } & \multirow[t]{2}{*}{ Commercial Pectin } \\
\hline & $A *$ & $\mathrm{~B}^{*}$ & $C^{*}$ & \\
\hline Yield (\%) & $36.45 \pm 0.27^{\mathrm{a}}$ & $34.86 \pm 0.21^{\mathrm{a}}$ & $36.21 \pm 1.4^{\mathrm{a}}$ & - \\
\hline Moisture (\%) & $7.9 \pm 0.01^{\mathrm{a}}$ & $8.17 \pm 0.16^{\mathrm{a}}$ & $10.72 \pm 0.27^{b}$ & $10.49 \pm 0.04^{b}$ \\
\hline FA (meq free carboxyl/g) & $3.01 \pm 0.34 \mathrm{~d}$ & $2.04 \pm 0.05^{c}$ & $1.73 \pm 0.29 \mathrm{~b}$ & $0.733 \pm 0.0^{\mathrm{a}}$ \\
\hline Equivalent weight (mg) & $400.37 \pm 2.98^{a}$ & $622.25 \pm 0.0^{\mathrm{b}}$ & $706.74 \pm 0.0^{\mathrm{c}}$ & $1364.63 \pm 0.0^{\mathrm{d}}$ \\
\hline Methoxy (\%) & $10.12 \pm 0.12^{b}$ & $11.29 \pm 0.29^{c}$ & $9.00 \pm 0.78^{\mathrm{a}}$ & $10.56 \pm 0.2^{b}$ \\
\hline $\mathrm{ED} *(\%)$ & $52.05 \pm 0.59^{a}$ & $64.09 \pm 0.1^{b}$ & $62.41 \pm 1.52^{b}$ & $82.29 \pm 0.16^{c}$ \\
\hline $\mathrm{UA} *(\%)$ & $\mathrm{DD} *$ & $\mathrm{DD}^{*}$ & $81.59 \pm 5.04^{\mathrm{a}}$ & $72.87 \pm 0.16^{\mathrm{b}}$ \\
\hline
\end{tabular}

Values are expressed as mean \pm standard deviation. Similar letters in same line indicated no significant differences $(p<0.05) .{ }^{*}$ A: two stages of extraction acid hydrolysis and alcohol precipitation, B: three stages of extraction acid hydrolysis alcohol precipitation and pectin washing, C: two stages of extraction with $\mathrm{pH}$ adjustment before alcohol precipitation, FA: Free acidity, ED: Esterification degree, UA: Uronic acid, DD: Difficult to determine.

The methoxy content and the ED are chemical parameters related to the gelification rate and pectin solidification. Procedure A showed similar methoxy \% as commercial pectin; values higher than $8 \%$ are considered to be high methoxy pectin. ED $(\%)$ was significantly $(p<0.05)$ lower with the different pectin recuperation processes in comparison to commercial pectin. Nevertheless, all treatments showed high values of ED. The purity of the material can be determined by the UA content; values higher than $65 \%$ are accepted as high purity by the FAO, as is the case of the pectin obtained by procedure C. 


\subsection{Pectin Identification and Conformation}

The qualitative test for pectin identification and conformation was performed in the sample obtained with procedure $\mathrm{C}$ and compared to the commercial one; all the tests indicated positive results to pectin (Table 4).

Table 4. Qualitative tests for the identification and conformation of pectin.

\begin{tabular}{ccccc}
\hline \multirow{2}{*}{ Test } & \multicolumn{2}{c}{ Laboratory Pectin } & & \multicolumn{2}{c}{ Commercial Pectin } \\
\cline { 2 - 5 } & Description & Result & Description & Result \\
\hline Pectin solution + ethanol & Yellow gelatinous pp & + & Sandy color gelatinous pp * & + \\
Pectin solution $+\mathrm{NaOH} 2 \mathrm{~N}$ & Yellow gel & + & Sandy color gel & + \\
Precipitated gel + HCl 3N & Colorless gelatinous pp & + & Colorless gelatinous pp * & + \\
\hline
\end{tabular}

\subsection{Evaluation of Pectin as Functional Ingredient}

The addition of pectin in cookie elaboration was performed at $2.5 \%, 7 \%$, and $10 \%$ of fat substitution. The results of water content, $\mathrm{a}_{\mathrm{W}}$, physical characterization, and texture of the resulting cookies are shown in Table 5. The water content in samples was between $5.3 \%$ and $8.3 \%$; this parameter is related to the capability of the cookie to absorb water. The control and treatment with $2.5 \%$ of pectin substitution presented the lower water \% content $(0.45)$ and increased $(\approx 0.48)$ for the treatments with $7 \%$ and $10 \%$ of pectin substitution. Diameter and thickness measurements of the cookies indicated that higher substitution significantly decreased these values, nevertheless, the largest spread ratio was obtained with the highest pectin substitution. Textural hardness indicated that there were not significant differences $(p<0.05)$ among the substitution concentrations and control treatments. The result values were in the interval of $18.3-20.6 \mathrm{~N}$, which indicates the presence of a soft cookie that did not feature drastic fracturing of the components.

Table 5. Water content, $A_{W}$, physical characterization, and texture analysis of the resulting cookies with added citric pectin.

\begin{tabular}{|c|c|c|c|c|c|c|}
\hline \multirow[b]{2}{*}{ Treatments } & \multirow{2}{*}{$\begin{array}{c}\text { Water } \\
\text { Content }(\%)\end{array}$} & \multirow[b]{2}{*}{$A_{W}$} & \multicolumn{3}{|c|}{ Physical Characterization } & \multirow{2}{*}{$\begin{array}{l}\text { Hardness } \\
\text { (N) }\end{array}$} \\
\hline & & & $\begin{array}{c}\text { Diameter } \\
(\mathrm{mm})\end{array}$ & $\begin{array}{c}\text { Thickness } \\
(\mathrm{mm})\end{array}$ & $\begin{array}{c}\text { Spread } \\
\text { Ratio }\end{array}$ & \\
\hline Control & $5.39 \pm 0.3^{a}$ & $0.44 \pm 0.02^{a}$ & $50.12 \pm 0.15^{b}$ & $10.45 \pm 0.15^{c}$ & 4.80 & $19.9 \pm 3.3^{\mathrm{a}}$ \\
\hline $2.5 \%$ of $P S *$ & $5.42 \pm 0.5^{\mathrm{a}}$ & $0.45 \pm 0.01^{\mathrm{a}}$ & $50.05 \pm 0.12^{b}$ & $10.35 \pm 0.17^{c}$ & 4.83 & $20.6 \pm 2.1^{\mathrm{a}}$ \\
\hline $7 \%$ of PS & $8.23 \pm 0.4^{b}$ & $0.49 \pm 0.02^{b}$ & $47.50 \pm 0.1^{\mathrm{a}}$ & $9.92 \pm 0.11^{b}$ & 4.78 & $18.3 \pm 3.2^{\mathrm{a}}$ \\
\hline $10 \%$ of PS & $7.65 \pm 0.1^{b}$ & $0.48 \pm 0.01^{b}$ & $48.3 \pm 0.11^{\mathrm{a}}$ & $9.68 \pm 0.02^{\mathrm{a}}$ & 4.99 & $18.9 \pm 3.2^{\mathrm{a}}$ \\
\hline
\end{tabular}

Values are expressed as mean \pm standard deviation. ${ }^{*}$ PS: pectin substitution. Similar letters in the same line indicate no significant differences $(p<0.05)$.

\section{Discussion}

\subsection{Flour Citrus Waste Characterization}

Moisture \% of the citrus waste flour is in concordance to the Mexican normativity for flour materials NOM 247-SSAI-2008 [23], which indicates a maximal value of $15 \%$; this is an important parameter to ensure the preservation of the material, reducing the risk of microbial contamination and enzymatic degradation that could reduce polyphenols and pectin yields. $\mathrm{pH}$ is related to the acidity presented in citrus residues that could be reduced by the dehydration process due to the salts dissociation as reported by Badillo [22], who obtained $\mathrm{pH}$ values of 5.5 for fresh fruits and 3.2 after dehydration. Total titrable acidity is related to the citric acid presence that might remain in the peel waste after juice extraction [22]. The slight dark coloration of citrus waste flours could be related 
to the natural pigments and sugars present in the products that could be partial degraded during waste drying, nevertheless the luminosity value higher than $60 \%$ indicates that the elaborated flour presented the possibility of preserving the quality of the by-products (polyphenols and pectin) that can be extracted from it.

\subsection{TPC, Antioxidant Activity, and Polyphenol Profile}

The importance of the polyphenol extraction method used in this study is related to the use of solid carbon dioxide, which favors a higher disruption of the vegetal matrix, which combines with the solvent, and promotes faster liberation of the phytochemicals compounds. A faster extraction process reduces the possibility of degradation to the polyphenols biological activity occurring due to heating and time consuming methods [24]. Furthermore, the total polyphenol content was higher than the results reported by Li et al. [25] and similar to the values obtained by Wang et al. [26] in citrus residues; in both cases, they used methanol as an extraction solvent. However, the TPC value was lower than the values mentioned by Papoutsis et al. [27]; this can be explained due to the different conditions used by these authors for drying peel preparation prior to TPC extraction with hot water, furthermore, the species of the citrus residue evaluated was also different (C. limon). Additionally, in our case, a lower TPC content could also be attributed to a previous essential oil extraction that could take part of the polyphenols presents in the peel and increase polyphenolic degradation before flour preparation. Although it has been reported [24] that a soft heat pre-treatment of the vegetal matrix (like the drying process) could enhance polyphenol extractions due to the previous disruption of the vegetal structures that favor polyphenol liberation, there are different conditions such as: pre-treatments methods, and different solvents and extraction conditions that can reduce or improve TPC yield [24]. Related to the antioxidant activity, the values reported herein are promising due to the preservation of more than $70 \%$ of the antioxidant activity. It has been reported that principal polyphenol compounds present in lemon residues, such as the flavonoids hesperidin and eriocitrin, may also have a major part in the antioxidant effect [28]. In this study, hesperidin is the second major compound detected, although the presence of eriocitrin was not determined due to the lack of the standard for the quantification analysis, the presence of unidentified peaks in the chromatogram was observed. If the methanolic polyphenol extraction is performed for further applications in the food industry, in all the cases a total elimination of the methanol content by evaporation is required for the restriction of methanol presence in food products, as reported by FDA. Phenolic compounds extracted from citrus waste could be excellent functional ingredients in the food industry and especially in bakery products due to the presence of antioxidant activity, nevertheless the sensitivity of the compounds suggests the use of encapsulation matrix to preserve their biological activities.

\subsection{Pectin Extraction}

For pectin extraction, all the factors evaluated presented a significantly effect. The solubilization of protopectin depends on a control acidic medium during the extraction process as well as the temperature and time [29]. A better pectin yield was obtained with citric acid than acetic or hydrochloric acid. Stronger acids could breakdown the polysaccharide bonds and reduce pectin yield; furthermore, the hydroxyl groups of the citric acid benefits the formation of hydrogen bonds between pectin and the citric acid favoring extraction [29]. As is indicated in results section, the Pareto analysis showed that conditions with higher values resulted in higher extraction yields; hence $90 \mathrm{~min}$ of time extraction and a ratio of 1:80 resulted in higher pectin yields regardless of the type of acid used. Pectin yields obtained in this work are comparable with those obtained from apple and citrus $(10 \%-40 \%)$ at laboratory scale [29]. The use of citric acid that favors pectin yield also promotes the application of green technologies to pectin production, reducing the generation of hydrochloric acid residues. 


\subsection{Physicochemical Pectin Characterization}

Pectin characteristics depend principally on the vegetal source as well as extraction conditions. Pectin moisture content along with all the physicochemical parameters of pectin is related to the quality of the product as it indicates the water absorption capability. Thus, pectin obtained with treatment $C$ presented similar pectin moisture as the commercial pectin, indicating similar water absorption capability during storage at ambient temperature. Titratable acidity values were higher than those obtained in the literature [17]. This might be due to the residue evaluated and the ripening stage, as well as the residues of the citric acid used during extraction. The equivalent weight is associated with the maturity stage of the fruit and is inversely proportional to the free acidity; this parameter is related to the gelling power and viscosity of the resulted pectin. Ferreira et al. [30] determined the equivalent weight of different citric fruits, obtaining values between 528 and $1130 \mathrm{mg}$; thus, the values obtained herein between 400 and $750 \mathrm{mg}$ are similar to the values reported elsewhere. Madhav and Pushpalatha [31] characterized pectins from different fruits, and found high methoxy pectins for citric sources of around $9 \%$, as was found in this work. This value is similar to the values obtained for pomelo pectins [32]. Characterization of pectin from citrus residues (Citrus $x$ latifolia) requires further analysis to study rheological parameters that can influence pectin application. However, considering its characteristic of forming gels, these pectins could also be used for medical applications [5] or to fabricate new entrapment bio-composites for probiotic delivery in the food industry [33].

\subsection{Evaluation of Pectin as Functional Ingredient}

As reported in the results section, the addition of pectin increased water content, although up until a $3 \%$ addition of pectin the conditions evaluated did not cause a significant difference in texture analysis. Thus, these results suggest the use of pectin from Citrus $x$ latifolia flour residues could be used as a fat replacement in bakery products due to the capability of this pectin to trap water and to give weight to the product without increasing calories. Further analyses to increase substitution values and sensorial analyses are needed in order to obtain a healthy and high quality product, nevertheless an approximation of a functional application is given in this work.

\section{Conclusions}

The interaction between the temperature and acid type, as well as the individual factors: extraction time, solute-solvent ratio, acid type, and temperature presented a significant effect $(p<0.5)$ on the yield of pectin extracted from Persian lime Citrus $x$ latifolia waste flour. According to the multifactorial variance analysis, the best extraction conditions were: citric acid at $90{ }^{\circ} \mathrm{C}$ for $90 \mathrm{~min}$ at a ratio of $1: 80(w / v)$ with a yield of $36 \%$ (g of pectin recovered per $g$ of flour used). The evaluation of pectin recuperation process on the pectin physicochemical characteristics indicated that the best treatment was obtained with neutralization before precipitation. Using these conditions, a pectin with moisture content of $10.72 \%$, free acidity of $1.73 \mathrm{meq}$ free/g carboxyl equivalent weight of $706.74 \mathrm{mg}$, methoxy content of $9.0 \%$, esterification degree of $62.41 \%$, uronic acid of $81.59 \%$, and yield of $36.21 \%$ can be obtained. The pectin was also categorized as having high methoxy, slow gelation, and a high degree of purity. Polyphenols profile determination indicated the major presence of the flavonoids neohesperidin and hesperidin in the residue with a TPC of $3.9 \mathrm{mg}$ of GAE/g of citrus waste flour DB and a value higher than $73 \%$ for antioxidant activity. The application of the citrus pectin as fat replacer in the cookies elaboration indicated a potential functional use of the pectin extracted using the best conditions observed. The characterization of pectin allowed for the determination of the characteristics of pectins that might be useful in other commercial applications.

Acknowledgments: The authors wish to thank Proyecto Fomix Yuc-2011-C09-0169165 for the financial support to the experimental work and for Cristina A. Ramos-Chan's scholarship. 
Author Contributions: Neith A. Pacheco L. and Teresa del Rosario Ayora-Talavera conceived and designed the experiments, the corresponding author Neith A. Pacheco L. also analyzed and wrote the paper, Cristina A. Ramos-Chan and Ana G. Covarrubias-Cárdenas performed the experiments, Angeles Sánchez-Contreras and Ulises García-Cruz contributed to the discussion and analysis of data.

Conflicts of Interest: The authors declare no conflict of interest.

\section{References}

1. SIAP-Agri-Food and Fisheries Information Service. (2014). SIAP gob.mx. Available online: http://www. siap.gob.mx/agricultura-produccion-anual/ (accessed on 16 July 2016).

2. Baltazar, R.; Carbajal, D.; Baca, N.; Salvador, D. Optimization of the conditions of pectin extraction from lemon rind french (Citrus medica) using response surface methodology. Agroind. Sci. 2013, 2, 77-89. [CrossRef]

3. Casquete, R.; Castro, S.M.; Martín, A.; Ruiz-Moyano, S.; Saraiva, J.A.; Córdoba, M.G.; Teixeira, P. Evaluation of the effect of high pressure on total phenolic content, antioxidant and antimicrobial activity of citrus peels. Innov. Food Sci. Emerg. Technol. 2015, 31, 37-44. [CrossRef]

4. Benavente-García, O.; Castillo, J. Update on uses and properties of citrus flavonoids: New findings in anticancer, cardiovascular, and anti-inflammatory activity. J. Agric. Food Chem. 2008. [CrossRef] [PubMed]

5. Gil-Izquierdo, A.; Riquelme, M.T.; Porras, I.; Ferreres, F. Effect of the Rootstock and Interstock Grafted in Lemon Tree (Citrus limon (L.) Burm.) on the Flavonoid Content of Lemon Juice. J. Agric. Food Chem. 2004, 52, 324-331. [CrossRef] [PubMed]

6. Sungthongjeen, S.; Sriamornsak, P.; Pitaksuteepong, T.; Somrisi, A.; Puttipipatkhachorn, S. Effect of degree of esterification of pectin and calcium amount on drug release from pectin-based matrix tablets. AAPS PharmSciTech 2009, 5, 50-57.

7. Luppi, B.; Bigucci, F.; Abruzzo, A.; Corace, G.; Cerchiara, T.; Zecchi, V. Freeze-dried chitosan/pectin nasal inserts for antipsychotic drug delivery. Eur. J. Pharm. Biopharm. 2010, 75, 381-387. [CrossRef] [PubMed]

8. Sriamornsak, P. Application of pectin in oral drug delivery. Expert Opin. Drug Deliv. 2011, 8, $1009-1023$. [CrossRef] [PubMed]

9. Glinsky, V.V.; Raz, A. Modified citrus pectin anti-metastatic properties: One bullet, multiple targets. Carbohydr. Res. 2009, 344, 1788-1791. [CrossRef] [PubMed]

10. Munarin, F.; Tanzi, M.C.; Petrini, P. Advances in biomedical applications of pectins gels. Int. J. Biol. Macromol. 2012, 51, 681-689. [CrossRef] [PubMed]

11. Chan, S.Y.; Choo, W.S.; Young, D.J.; Loh, X.J. Pectin as a rheology modifier: Origin, structure, commercial production and rheology. Carbohydr. Polym. 2017, 161, 118-139. [CrossRef] [PubMed]

12. Lim, J.; Ko, S.; Lee, S. Use of Yuja (Citrus junos) pectin as a fat replacer in baked foods. Food Sci. Biotechnol. 2014, 23, 1837-1841. [CrossRef]

13. Norma Oficial Mexicana NMX-F-428. Determinación de Humedad (Método Rápido de la Termobalanza). 1982. Available online: http://www.colpos.mx/bancodenormas/nmexicanas/NMX-F-428-1982.PDF (accessed on 10 September 2015).

14. Sánchez-Contreras, A.; Rufino-Gonzalez, Y.; Ponce-Macotela, M.; Sánchez-Garcia, S.; Jiménez-Estrada, M.; Rodriguez-Buenfil, I.; Chel-Guerrero, L. Psidium guajava and Tagetes erecta flavonoids: Isolation, identification and biological activity. In Nutraceuticals Funct Foods Conv Non-Conventional Sources; Studium Press: Houston, TX, USA, 2011; pp. 64-71.

15. Vasco, C.; Ruales, J.; Kamal-Eldin, A. Total phenolic compounds and antioxidant capacities of major fruits from Ecuador. Food Chem. 2008, 111, 816-823. [CrossRef]

16. Chen, M.L.; Yang, D.J.; Liu, S.C. Effects of drying temperature on the flavonoid, phenolic acid and antioxidative capacities of the methanol extract of citrus fruit (Citrus sinensis (L.) Osbeck) peels. Int. J. Food Sci. Technol. 2011, 46, 1179-1185. [CrossRef]

17. Gamboa, B.M.; Universidad de Oriente, Núcleo de Anzoátegui, Puerto la Cruz, Venezuela. Aprovechamiento de los Residuos Obtenidos del Proceso de Despulpado del Mango (Mangifera indica L.) Como Materias Primas Para la Obtención de Pectinas. Personal Communication, 2009.

18. Mohd, N.; Ramli, N.; Meon, H. Extraction and characterization of pectin from Dragon Fruit (Hylocereus polyhizus) using various extraction conditions. Sains Malays. 2012, 41, 41-45.

19. Pomeranz, Y.; Meloan, C.E. Food Analysis: Theory and Practice, 3rd ed.; Springer Science \& Business Media, An Aspen Publication, Aspen Publishers, Inc.: Gaitherburg, MD, USA, 2000. 
20. Handa, C.; Goomer, S.; Siddhu, A. Effects of Whole-Multigrain and Fructoligosaccharide incorporation on the Quality and Sensory Attributes of cookies. Food Sci. Technol. Res. 2011, 17, 45-54. [CrossRef]

21. Sudha, M.L.; Srivastava, A.K.; Vetrimani, R.; Leelavathi, K. Fat replacement in soft dough biscuits: Its implications on dough rheology and biscuit quality. J. Food Eng. 2007, 80, 922-930. [CrossRef]

22. Badillo, M.D.; Escuela Superior Politécnica de Chimborazo, Riobamba, Ecuador. Estudio Comparativo del Potencial Nutritivo de Limón Persa (Citrus latifolia tanaka) Deshidratado en Secador de Bandejas y en Microondas. Personal Communication, 2011.

23. Norma Oficial Mexicana NOM-247-SSA1. Productos y Servicios. Cereales y sus Productos. Cereales, Harinas de Cereales, Sémolas o Semolinas. 2008. Available online: http://depa.fquim.unam.mx/amyd/archivero/ NOMcereales_12434.pdf (accessed on 8 September 2015).

24. Baas-Dzul, L.V.; Centro de Investigación y Asistencia en Tecnología y Diseño del Estado de Jalisco A.C. Mérida México. Obtención de Extractos Polifenólicos con Actividad Biológica a Partir de Harinas Elaboradas con Subproductos de Limón Italiano. Personal Communication, 2015.

25. Li, B.; Smith, B.; Hossain, M. Extraction of phenolics from citrus peels I. solvent extraction method. Sep. Purif. Technol. 2006, 48, 182-188. [CrossRef]

26. Wang, Y.; Chueh, Y.; Hsing, W. The flavonoid, carotenoid and pectin content in peels of citrus cultivated in Taiwan. Food Chem. 2008, 106, 277-284. [CrossRef]

27. Papoutsis, K.; Pristijono, P.; Golding, J.B.; Stathopoulos, C.E.; Bowyer, M.C.; Scarlett, C.J.; Vuong, Q.V. Effect of vacuum-drying, hot air-drying and freeze-drying on polyphenols and antioxidant capacity of lemon (Citrus Limon) pomace aqueous extracts. Int. J. Food Sci. Technol. 2017. [CrossRef]

28. Del Río, J.A.; Fuster, M.D.; Gómez, P.; Porras, I.; García-Lidón, A.; Ortuño, A. Citrus limon: A source of flavonoids of pharmaceutical interest. Food Chem. 2004, 84, 457-461. [CrossRef]

29. Canteri, M.H.; Ramos, H.C.; Waszczynskyj, N.; Wosiacki, G. Extraction of pectin from Apple pomace. Braz. Arch. Biol. Technol. 2005, 48, 259-266. [CrossRef]

30. Ferreira, S. Aislamiento y caracterización de las pectinas de algunas variedades de frutos cítricos colombianos. Rev. Colomb. Cienc. Quím. Farm. 1976, 3, 5-25.

31. Madhav, A.; Pushpalatha, P. Characterization of pectin extracted from different fruit wastes. J. Trop. Agric. 2002, 40, 53-55.

32. Methacanon, P.; Krongsin, J.; Gamonpilas, C. Pomelo (Citrus maxima) pectin: Effects of extraction and its properties. Food Hydrocoll. 2013, 30, 1-9. [CrossRef]

33. Khorasani, A.C.; Shojaosadati, S.A. Pectin-non-starch nanofibers biocomposites as novelgastrointestinalresistant prebiotics. Int. J. Biol. Macromol. 2017, 94, 131-144. [CrossRef] [PubMed]

(C) 2017 by the authors. Licensee MDPI, Basel, Switzerland. This article is an open access article distributed under the terms and conditions of the Creative Commons Attribution (CC BY) license (http:/ / creativecommons.org/licenses/by/4.0/). 